\title{
Population dynamics of Cyathura carinata (Isopoda) in a eutrophic temperate estuary
}

\author{
S.M. Ferreira*, M.A. Pardal, A.I. Lillebø, P.G. Cardoso, J.C. Marques \\ IMAR - Institute of Marine Research, Department of Zoology, University of Coimbra, 3004-517 Coimbra, Portugal
}

Received 13 April 2004; accepted 9 August 2004

\begin{abstract}
From January 1993 to September 1995, Cyathura carinata was a target species of a monitoring programme carried in the Mondego Estuary (Portugal). Being one of the key species of the intertidal mud flats, this isopod was found to be most abundant in a eutrophic area, where seasonal macroalgal blooms usually occur. Its density decreased towards downstream areas, where some Zostera noltii beds exist. At the Mondego Estuary, the present work stated that C. carinata: (a) had a 2-year life span, even though, $80-90 \%$ of the individuals died when 1 year old, revealing a strong post-reproduction mortality; (b) produced a single cohort per year; (c) showed continuous growth (with lower rates during winter); (d) evidenced protogynous hermaphroditism and (e) presented a high growth production and a low turnover ratio. A latitudinal gradient reflected in the life features of $C$. carinata was described. Except for the life span and the frequency of reproduction, which are generally valid for all populations, $C$. carinata from the Mondego Estuary fitted the characteristics of other populations from the south of Europe.

The effects of macroalgal blooms were assessed. Cyathura carinata seemed to temporarily benefit from the presence of macroalgae, due to higher energy resources and more efficient protection against predators. In a long term, algal blooms had negative consequences. It was particularly evident on the recruitment success, which had repercussions in population abundance, and on the secondary production. Therefore, repeated events of algal blooms embracing the distribution areas of C. carinata represent a threat to this species in eutrophic estuaries.
\end{abstract}

(c) 2004 Elsevier Ltd. All rights reserved.

Keywords: Cyathura carinata; eutrophication; isopod; macroalgal bloom; population dynamics; secondary production

\section{Introduction}

Similar to other coastal systems worldwide (Everett, 1994; Norkko and Bonsdorff, 1996a,b; McMahon and Walker, 1998; Beukema et al., 1999; Norkko et al., 2000; Wooldridge and Callahan, 2000; Sfriso et al., 2001), the Mondego Estuary has been undergoing a eutrophication process (Marques et al., 1997, 2003; Martins et al., 1997, 2001; Pardal et al., 2000, 2004; Cardoso et al., 2002; 2004; Dolbeth et al., 2003). Apart from supporting several industries, this small temperate intertidal estua-

\footnotetext{
* Corresponding author.

E-mail address: smff@ci.uc.pt (S.M. Ferreira).
}

rine system (1600 ha) receives an agricultural run-off from 15000 ha of cultivated land (mostly rice and corn fields), upstream of its location. During the last 2 decades, there has been a seasonal proliferation of opportunistic green macroalgal species (e.g. Ulva sp.), parallel to a severe reduction of Zostera noltii beds, the richest habitats concerning productivity and biodiversity (Marques et al., 1997; Martins et al., 2001; Dolbeth et al., 2003; Cardoso et al., 2004).

Cyathura carinata (Krøyer, 1847) is an estuarine tubicolous isopod, widely distributed along the Atlantic coasts of Europe (Cléret, 1960; Legrand and Juchault, 1963; Amanieu, 1969; Bamber, 1985; Köhn and Sammour, 1990; Sola and Arzubialde, 1993; Marques et al., 1994), Baltic (Muus, 1967; Jażdżewski, 1969; 
Wägele, 1979; Ólafsson and Persson, 1986) and Mediterranean Seas (Argano, 1979). Previous studies about the macrobenthic community structure in the Mondego Estuary revealed $C$. carinata as one of the most abundant species, both in terms of density and biomass. Thus, the population dynamics of this isopod was studied during a 1-year period (Marques et al., 1994) and a population dynamics model was elaborated (Martins et al., 1997). The main objective of the present work is to follow the evolution of $C$. carinata's population in relation to the eutrophication processes occurring in the estuary. Also, it is intended to gather all the information about this species, most of it published until the middle 1980s, and compare it with the few recent publications. So, a long monitoring programme of 32 months was carried out, in order to: (a) clarify some of the questions raised by different authors, especially those that caused divergence of opinions, such as life span, recruitment frequency and evidence of protogynous hermaphroditism (a process by which some females sex reverse into males); (b) to evaluate the effects of macroalgal blooms on population dynamics, biology and production and (c) to assess if eutrophication processes may endanger the presence of this species in affected estuaries.

\section{Materials and methods}

\subsection{Study site and field programme}

The south arm of the Mondego Estuary (Fig. 1) is a shallow water system (2-4 m deep in high tide, with a tidal range of 1-3 m), where Zostera noltii beds covered most part of the intertidal areas more than 3 decades ago. Three different study locations were established along

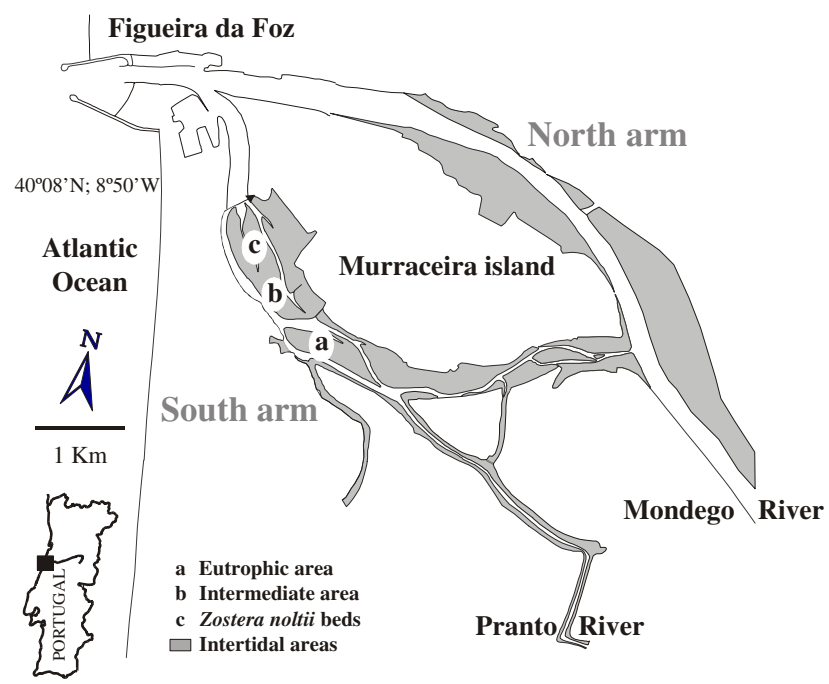

Fig. 1. Location of the sampling stations along the south arm of the Mondego Estuary. a spatial gradient, according to different eutrophication symptoms (Fig. 1). (a) The eutrophic area, a sandier mudflat in the inner parts of the estuary, from where $Z$. noltii disappeared without trace more than 25 years ago and where seasonal green macroalgal blooms occur (Ulva sp.). This site is characterised by higher total inorganic nitrogen concentrations of the water $(30$ $50 \mu \mathrm{mol} \mathrm{N}{ }^{-1}$ ) and lower salinity values (15.0-25.0), water-flow velocities $\left(0.8-1.2 \mathrm{~m} \mathrm{~s}^{-1}\right)$ and organic matter content of the sediment $(3.7 \pm 1.0 \%$, mean \pm S.D.). (b) The intermediate area, located in the middle section, is a mudflat that had $Z$. noltii coverage until 5 years prior to this study, where some rhizomes could be found still. Its physical-chemical conditions are relatively similar to the third area. (c) The Z. noltii beds, located downstream, correspond to a relatively non-eutrophic area. This site is characterised by lower total inorganic nitrogen concentrations of the water $\left(15-30 \mu \mathrm{mol} \mathrm{N} 1^{-1}\right)$ and higher salinity values $(20.0-30.0)$, water-flow velocities $\left(1.2-1.4 \mathrm{~m} \mathrm{~s}^{-1}\right)$ and organic matter content of the sediment (6.8 $\pm 1.0 \%$, mean \pm S.D.) (Martins et al., 2001).

Sampling was carried out from January 1993 to September 1995. Random samples were collected fortnightly in the first 18 months and monthly thereafter. For every sampling date, at each station, temperature, salinity, $\mathrm{pH}$ and dissolved oxygen were measured in situ, in low water pools. At each study area, 6-10 cores $(13.5 \mathrm{~cm}$ diameter) were taken to a depth of $15 \mathrm{~cm}$, washed over a $0.5 \mathrm{~mm}$ mesh sieve and preserved in $4 \%$ buffered formalin. Later, animals were separated and kept in $70 \%$ ethanol. Sorted plant material from all the cores (Chlorophyceae and Zostera noltii leaves and rhizomes) was dried during $48 \mathrm{~h}$ at $60{ }^{\circ} \mathrm{C}$ and weighed. Afterwards, the ash free dry weight (AFDW) was determined by loss on ignition $\left(8 \mathrm{~h}\right.$ at $\left.450{ }^{\circ} \mathrm{C}\right)$.

\subsection{Laboratory procedures}

Cyathura carinata individuals were counted, measured for cephalic length and sexed, according to previous literature (Cléret, 1960; Bamber, 1985; Olafsson and Persson, 1986; Marques et al., 1994). Total body length $(\mathrm{mm})$ and biomass ( $\mathrm{g}$ of AFDW) of each individual were determined from cephalic length using regression models (total body length $=0.745133+$ $9.01010 \times$ cephalic length, $r^{2}=0.968521, \quad N=115$ and biomass $=0.0190549 \times$ cephalic length $^{2.71815}, r^{2}=$ $0.964352, N=800$ ) established by Marques et al. (1994).

Embryos were removed from gravid females, counted, measured and classified in 3 developmental stages, according to literature (Jażdżewski, 1969; Bamber, 1985; Ólafsson and Persson, 1986; Marques et al., 1994): (a) stage A, corresponding to oval homogeneous embryos, recently laid; (b) stage B, referring to elongated embryos, sometimes with pereiopods and antennae already identifiable; and (c) stage $\mathrm{C}$, indicating newly 
hatched juveniles still inside the brood pouch of the female.

\subsection{Statistical analysis}

Multiple regression models were developed to relate the variation of Cyathura carinata density, biomass and abundance of juveniles with physical-chemical factors and vegetation biomass. The variables were subjected to suitable transformations, when necessary, to fulfil required assumptions of homocedasticity and normality of the data (Zar, 1996). The C. carinata population structure was defined by tracking recognisable cohorts from successive sampling dates through size-frequency distribution analysis, performed by ANAMOD software, based on the probability paper method (Cassie, 1954). Reliability was checked by application of $\chi^{2}$ and $G$ tests $(P=0.05)$.

The equation of Gaschütz et al. (1980) was used to express field growth rates because it takes into account seasonal variations. It is expressed as: $L_{t}=$ $L_{\infty}\left(1-\exp \left(-\left[k D\left(t-t_{0}\right)+C(k D / 2 \pi) \sin 2 \pi\left(t-t_{\mathrm{s}}\right)\right]\right)\right) 1 / D$, where $L_{t}$ is the length of the organism at a given moment $t ; L_{\infty}$ the maximum possible length of the organism; $t_{0}$ the instant when the organism would have a length equal to $0 ; t_{\mathrm{s}}$ the time interval between the start of growth (when $t=0$ ) and the first growth oscillation, being growth expressed by a sine curve with a 1-year period; $k$ the intrinsic growth rate; $C$ the parameter in which the values can range from 0 to 1 , depending on the species; and $D$ the parameter that expresses metabolic deviations from the von Bertalanffy's $2 / 3$ rule.

Annual production estimates were based upon cohort recognition. The values of $P$ for the population followed the procedures and techniques used by Pardal et al. (2000), Cardoso et al. (2002) and Dolbeth et al. (2003), expressed as: $P=\sum_{n=1}^{N} P_{\mathrm{c} n}$, where $P_{\mathrm{c} n}$ is the growth production of a cohort $n$. The mean population biomass $\bar{B}$ was calculated as: $\bar{B}=(1 / T) \sum_{n=1}^{N} \bar{B}_{n} t$, where $T$ is the period of study; $N$ the number of cohorts in the period $T ; \bar{B}_{n}$ the mean biomass of the cohort $n$ and $t$ the duration of that same cohort.

\section{Results}

\subsection{Macroalgae and macrophyte biomass}

Based on the green macroalgal biomass at the eutrophic area (Fig. 2a), there were differences between the spring periods from the 3 sampled years. During the first 6 months of 1993, there was a biomass increase, characteristic of a spring bloom (reaching $452 \pm 118 \mathrm{~g} \mathrm{~m}^{-2}$ AFDW, mean \pm S.E.), followed by its sudden disappearance in late June (algal crash). In contrast, no algal development was observed in 1994.

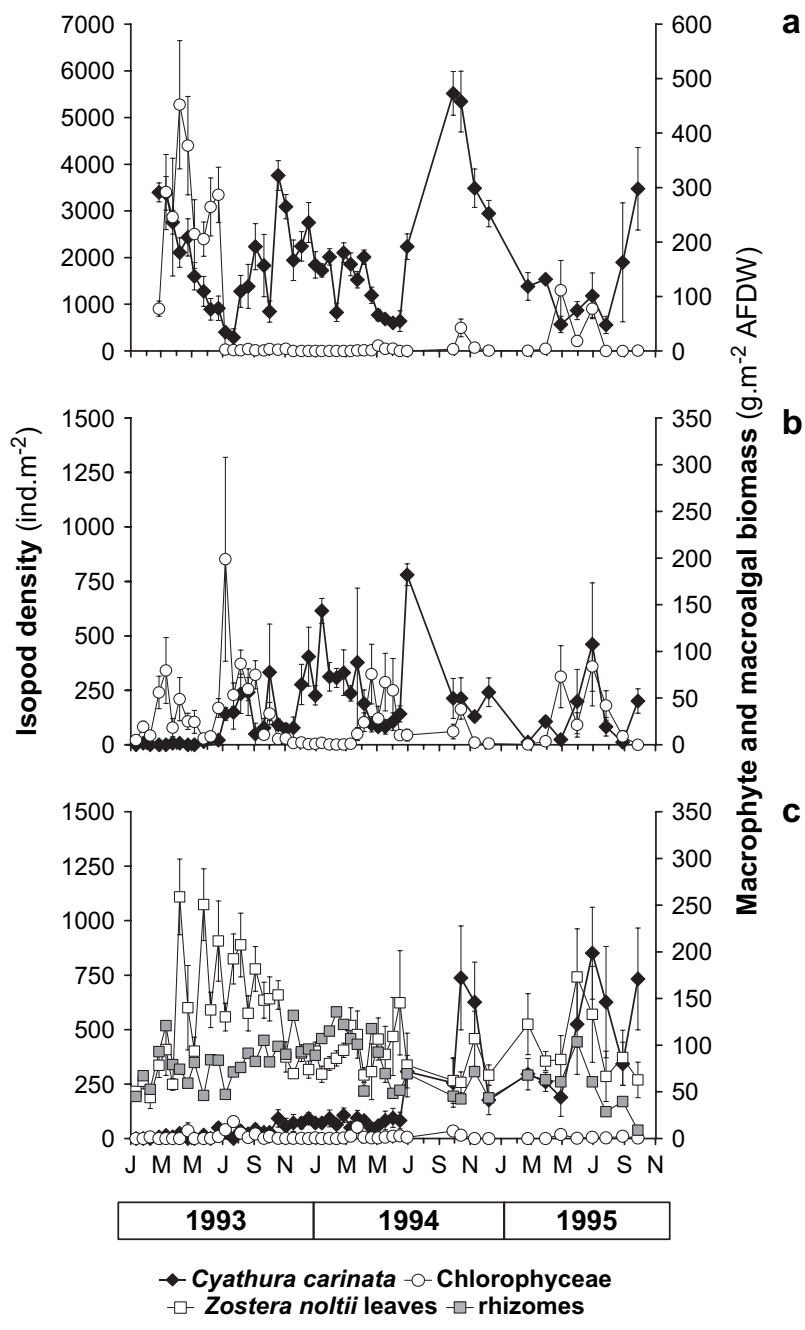

Fig. 2. Cyathura carinata abundance, macrophyte and macroalgal biomass variation (all expressed in mean \pm S.E.) at: (a) eutrophic area, (b) intermediate area and (c) Zostera noltii beds.

The following year was an intermediate situation, in which the macroalgal biomass reached $111 \pm 55 \mathrm{~g} \mathrm{~m}^{-2}$ AFDW (mean \pm S.E.). Along the south arm of the estuary, green macroalgae were especially abundant in the eutrophic area, decreasing towards Zostera noltii beds. The intermediate area (Fig. 2b) showed proportionally small abundance of green macroalgae, during the 3 consecutive years. In the downstream area, $Z$. noltii biomass gradually decreased throughout the entire period (Fig. 2c). Even so, it was possible to discern a seasonal pattern, in which the total biomass depended mostly on the growth of leaves during spring and summer, with rhizome biomass becoming dominant during autumn and winter.

\subsection{Spatial distribution and abundance}

Cyathura carinata densities varied spatially, being most abundant at the eutrophic area $\left(1851 \pm 169\right.$ ind. $\mathrm{m}^{-2}$, mean \pm S.E.) (Fig. 2a). The annual variation pattern was 
very regular. Maximum values were always achieved during autumn, declining continuously until late spring. Inter-annual differences mostly concerned autumn maxima of each year. In 1993 and 1995, when macroalgae occurred, the maxima densities (respectively $3759 \pm 319$ and $3475 \pm 884$ ind. $\mathrm{m}^{-2}$, mean \pm S.E.) were lower than in $1994\left(5518 \pm 470\right.$ ind. $\mathrm{m}^{-2}$, mean \pm S.E. $)$, when there was no algal development. Moreover, the initial density of $1993\left(3397 \pm 202\right.$ ind. $m^{-2}$, mean \pm S.E. $)$ was very close to the autumnal maximum of that year, when the population was already in decline, according to the density pattern.

The intermediate (Fig. 2b) and downstream (Fig. 2c) areas recorded lower densities $(172 \pm 24$ and $172 \pm$ 34 ind. $\mathrm{m}^{-2}$, mean \pm S.E., respectively). Indeed, Cyathura carinata was totally absent from Zostera noltii beds in the beginning of 1993. Nevertheless, density increased almost constantly throughout the study period, reaching the highest value of $851 \pm 255$ ind. $\mathrm{m}^{-2}$ (mean \pm S.E.) in June 1995 .

\subsection{Population structure, growth and life span}

Size-frequency polymodal distributions were analysed for recognisable cohorts (Fig. 3), taking only into account data from the eutrophic area (in fact, the methodology used could not be applied to the data sets from the other two areas, due to low abundances). It was possible to recognise 5 cohorts and establish that the population recruits only once a year (Fig. 4a). This observation is supported by the appearance of newly born cohorts, respectively $\mathrm{C}_{3}, \mathrm{C}_{4}$ and $\mathrm{C}_{5}$, around June each year. Therefore, it seems reasonable to assume that cohorts $\mathrm{C}_{1}$ and $\mathrm{C}_{2}$ resulted from recruitments that took place in 1991 and 1992. The population life span was estimated at $23 \pm 1$ months. Nevertheless, it is important to note that all cohorts suffered severe density reduction of $80-90 \%$ in the summer when the isopods completed 1 year of life (Fig. 4b). Such decreases coincided with recruitment periods and seemed to portray a strong post-reproduction mortality. Therefore, only $10-20 \%$ of the individuals may in fact reach the estimated life span of approximately 2 years.

The cohort $\mathrm{C}_{3}$ field data were used to calibrate a growth model (Fig. 4c). Growth was found to be continuous, although its rate varied with size (age) and temperature (season), being higher at early life stages and during spring and summer.

\subsection{Life cycle}

Cyathura carinata exhibited protogynous hermaphroditism, with males being present only between February and August (Fig. 5a). A continuous decrease of the sex ratio was noted throughout the study period, from 0.32 in 1993 to 0.16 in 1995.
Approximately one month and a half after the appearance of males, the first ovigerous females were detected, being found from March to September, with a peak around June (Fig. 5b). The juveniles' percentage variation confirmed that the population produced a single generation per year (Fig. 5b). Multiple regression analysis corroborated that the percentage of juveniles was correlated negatively to green macroalgal biomass and positively to water temperature during all the 32 months: arcsine $\sqrt{\text { juvenile } \% / 100}=-0.272-0.0446 \ln$ (green macroalgae +1$)+0.0303$ temperature $(N=46$; $\left.R^{2}=57.10 \%\right)$.

Consistently, embryos at different developmental stages could be found once a year, during spring and summer (Fig. 5c). Based on the time interval between the peaks of embryos in stages $\mathrm{A}$ and $\mathrm{C}$, the embryonic development was estimated to last about 45 days. Most ovigerous females were found with total or partially empty brood pouches. This accounts for most of the inconsistencies observed in the sequence of embryo stages. Preservation in formaldehyde led to an embryo loss, especially of those from the last stage, which are already able to survive on their own. Consequently, very few embryos (C) were observed and no reliable fecundity data could be presented.

\subsection{Production}

Annual and spring (February to June) productions were estimated to assess the effect of the presence/ absence of macroalgae. The annual growth production $(P)$ (Table 1) was higher in 1994, when no algae occurred. The respective spring period $\left(9.81 \mathrm{~g} \mathrm{~m}^{-2}\right.$ 4 months $^{-1}$ ) represented approximately $1 / 3$, suggesting that the production rate was regular during that year. On the other hand, the spring of $1993\left(20.14 \mathrm{~g} \mathrm{~m}^{-2}\right.$ 4 months $^{-1}$ ) represented more than $50 \%$ of the annual estimation.

The mean annual population biomass $(\bar{B})$ was also higher in the absence of macroalgae (Table 1). Nevertheless, the population biomass estimated during the macroalgal bloom in $1993\left(13.58 \mathrm{~g} \mathrm{~m}^{-2}\right)$ was much higher than the annual average, while in 1994 $\left(5.54 \mathrm{~g} \mathrm{~m}^{-2}\right)$ it was approximately half. With regard to $P / \bar{B}$ ratio (Table 1 ), no major differences were found between the 2 years or between the respective spring periods (1.48 in 1993 and 1.77 in 1994).

\section{Discussion}

\subsection{Spatial distribution and abundance}

A regular seasonal density pattern was observed in the eutrophic area, consistent with other European populations (Legrand and Juchault, 1963; Muus, 1967; 

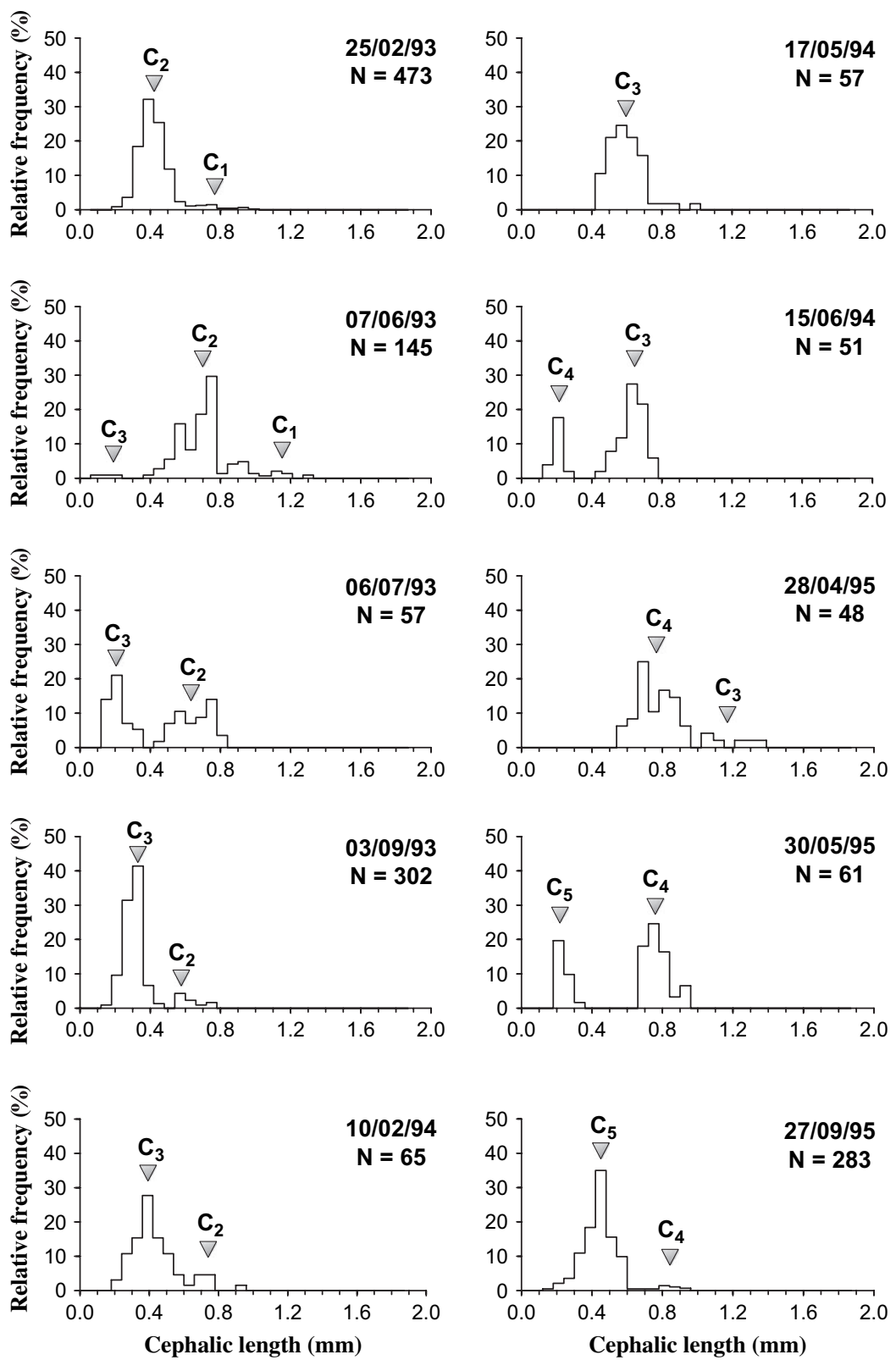

Fig. 3. Size-frequency distribution of Cyathura carinata in the eutrophic area. The identified cohorts are indicated (C), as well as the number of measured individuals $(N)$. Arrowheads indicate average cephalic length of the numbered cohorts.

Amanieu, 1969; Jażdżewski, 1969; Wägele, 1979; Bamber, 1985; Ólafsson and Persson, 1986; Köhn and Sammour, 1990; Sola and Arzubialde, 1993). Cyathura carinata showed a spatial variation, with the population decreasing from inner areas towards the Zostera noltii beds. There are references relating the presence of C. carinata in Zostera sp. and other macrophytes beds (Bamber, 1985; Sola and Arzubialde, 1993; Ólafsson and Persson, 1986). Therefore, the explanation for the low abundance initially recorded in the $Z$. noltii beds and subsequent increase remains unknown. Processes related with (a) the specific habitat selection by crustaceans, (b) the Z. noltii decline due to eutrophication, with consequent increase of habitat similarity with the eutrophic area, and (c) parasite pressure (Jensen et al., in press) may be some possible mechanisms that could explain the observed pattern.

\subsection{Population structure, growth and life span}

Cyathura carinata generated a single cohort per year, and not two consecutive ones that rapidly become merged, as stated by Marques et al. (1994). However, reproduction is extended through all summer, which may have allowed distinguishing two different intensity periods in that particular year. The approximately 2 years life span at the Mondego Estuary agrees with most observations in other populations (Legrand and 

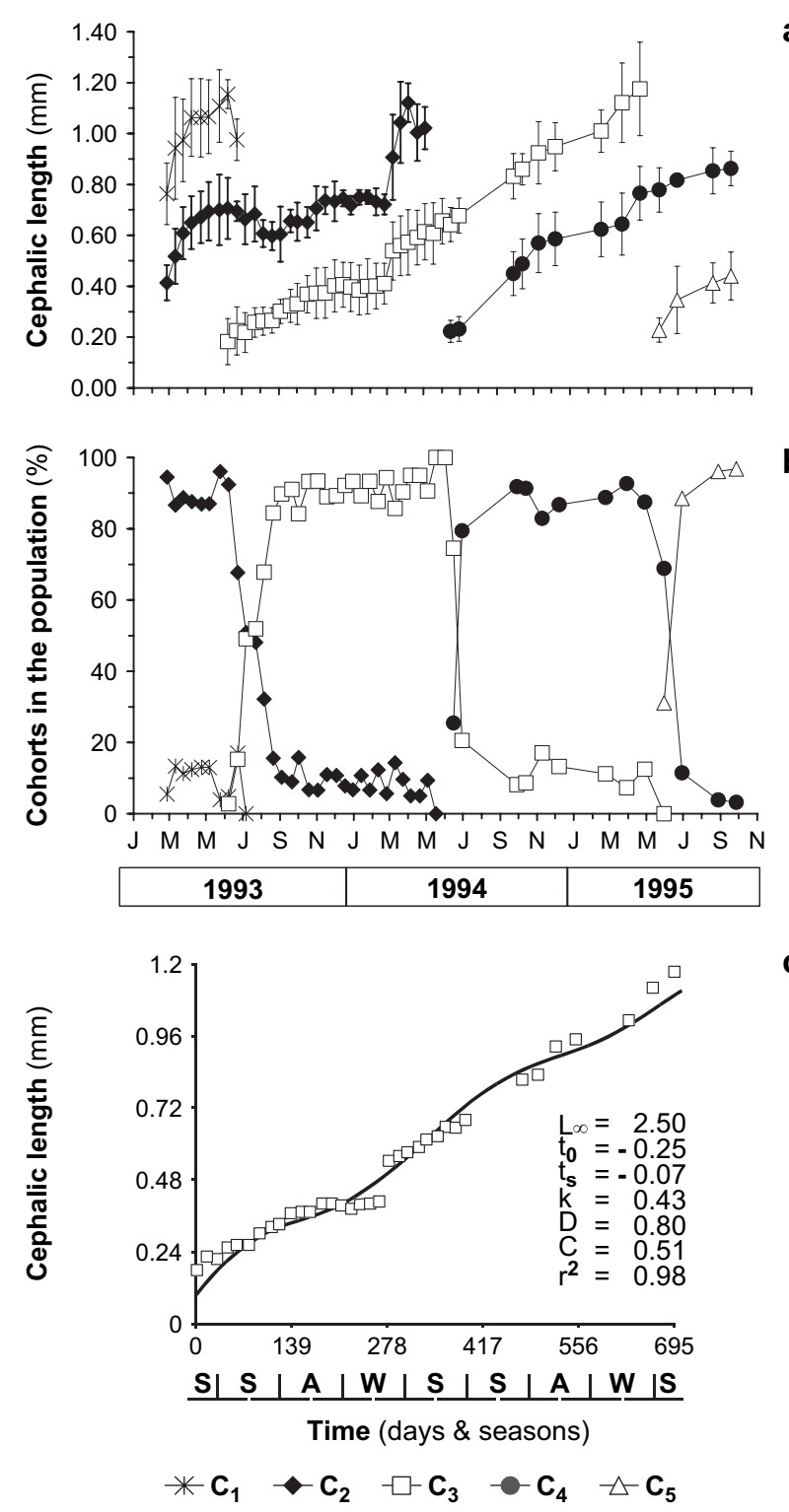

Fig. 4. Features of Cyathura carinata cohorts. (a) Linear growth of the identified cohorts (mean \pm S.D.); (b) relative frequency of isopods belonging to each of the cohorts identified in the eutrophic area; (c) growth model and respective parameter values.

Juchault, 1963; Muus, 1967; Bamber 1985; Ólafsson and Persson, 1986; Sola and Arzubialde, 1993). Only the ones from Puck Bay (Jażdżewski, 1969), Kiel Canal (Wägele, 1979), Wismar Bight (Köhn and Sammour, 1990) and Kingsnorth (Bamber, 1985) appeared to live 3 years. Nevertheless, as in the populations from Arcachon (Amanieu, 1969) and Bidasoa (Sola and Arzubialde, 1993), a strong reduction of $80-90 \%$ of the individuals took place at the end of the first year of life (in the beginning of each summer), which apparently corresponds to post-reproduction mortality (Table 1).

Growth was also consistent with the rates of populations at the south of Europe (Amanieu, 1969; Bamber, 1985; Sola and Arzubialde, 1993; Marques
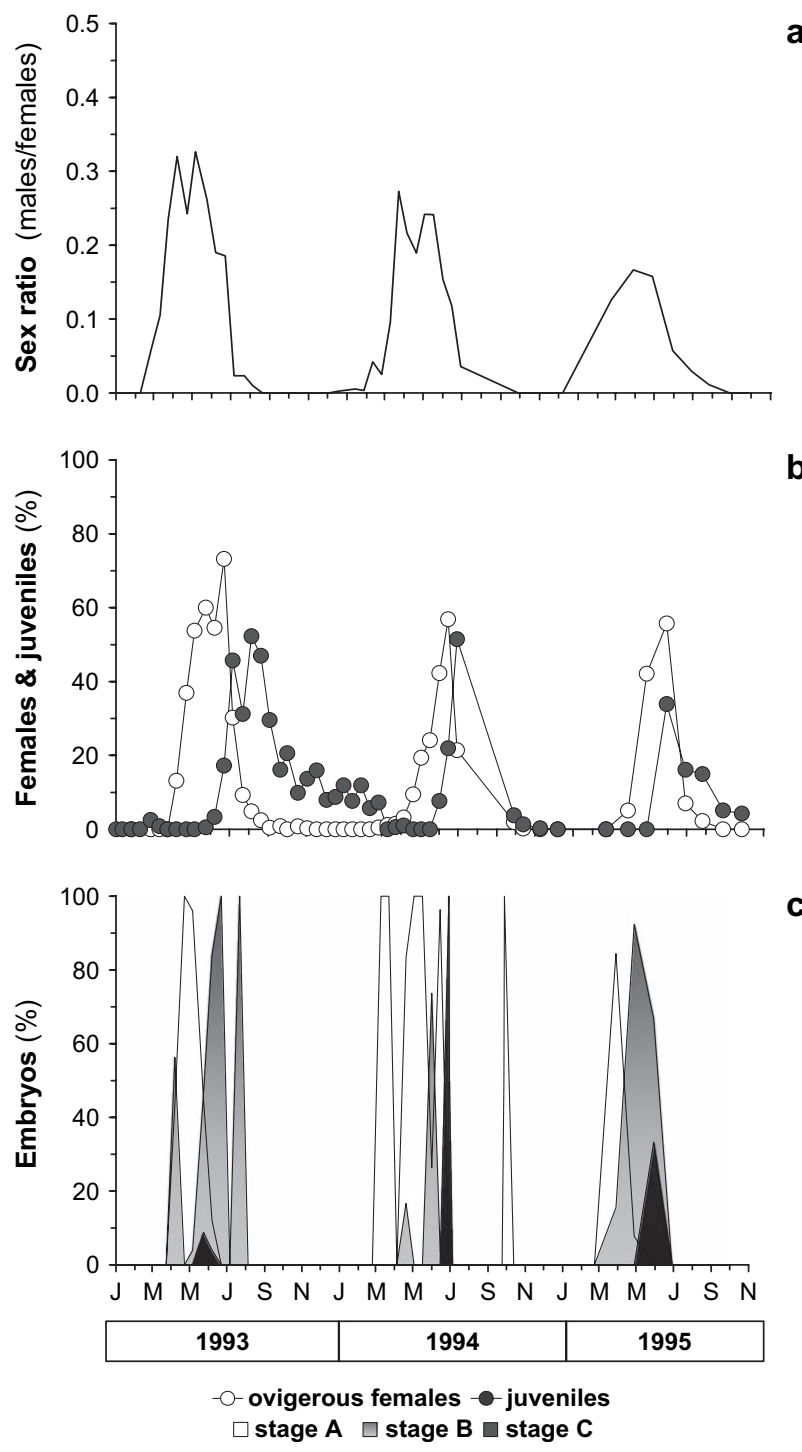

Fig. 5. Cyathura carinata's biological features. (a) Sex ratio variation (males/females); (b) comparison of the proportion of ovigerous females and juveniles in the population; (c) relative frequency of embryos at different development stages, during the study period.

et al., 1994), reducing during the coldest months of the year, but without ever ceasing as in the northern populations (Jażdżewski, 1969; Wägele, 1979; Ólafsson and Persson, 1986; Köhn and Sammour, 1990) (Table 1).

\subsection{Life cycle}

Like in other European populations (Legrand and Juchault, 1963; Jażdżewski, 1969; Wägele, 1979; Bamber, 1985; Sola and Arzubialde, 1993), protogynous hermaphroditism was observed. Males were usually larger individuals (the mean total length of the 100 biggest males was $10.7 \mathrm{~mm}$ against only $7.9 \mathrm{~mm}$ in reproductive females). Based on the fact that males appear one and a half months before ovigerous females and that most individuals were able to reproduce in their first year of 
Table 1

Summary of biological features from several Cyathura carinata populations, ordered from north to south (symbology: “-” absence of information, "av" average, "max" maximum, "min" minimum, "prot. herm." protogynous hermaphroditism and "C" cohort)

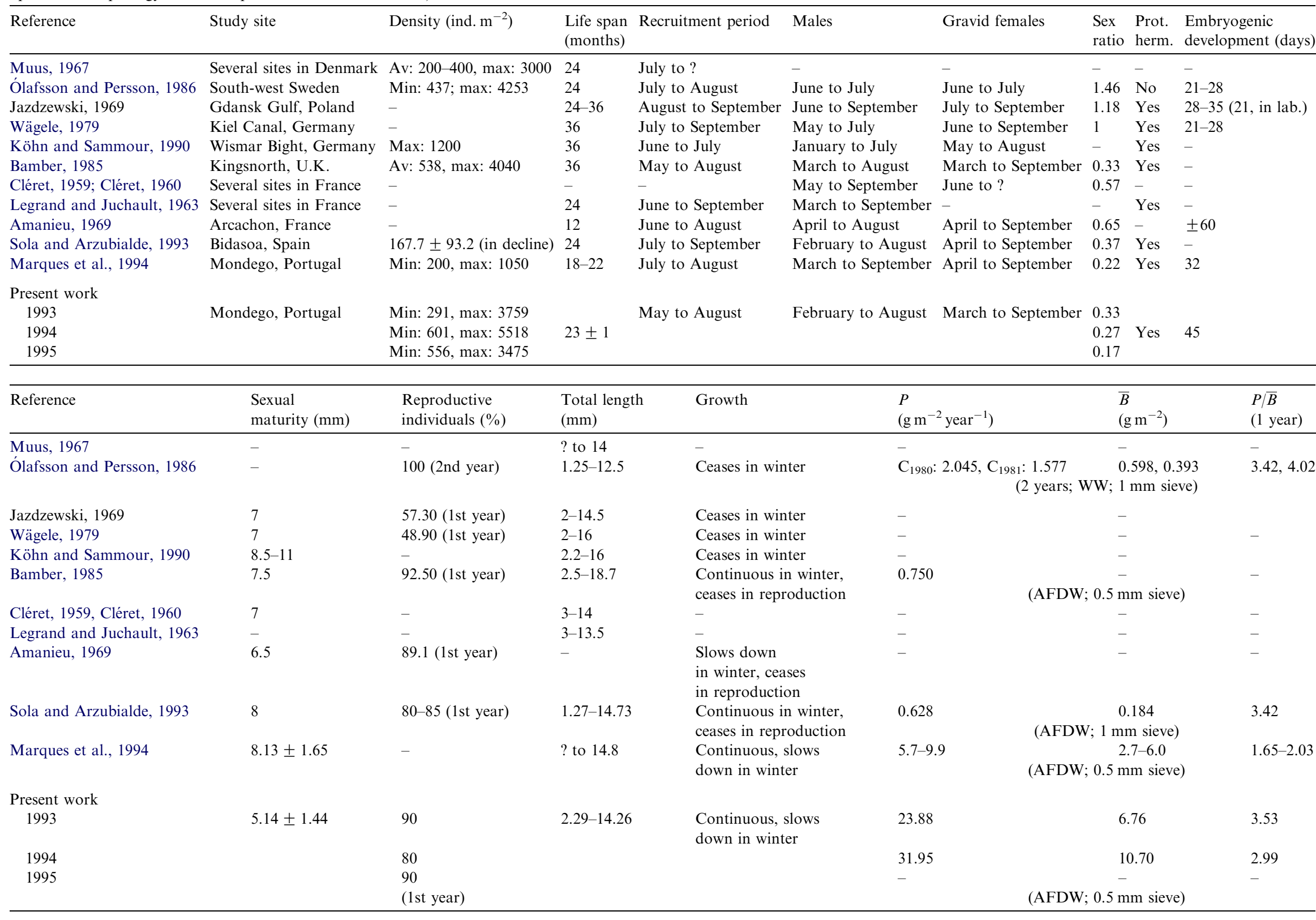


life, the sexual maturity of this isopod was estimated in 810 months. Since the northern populations grow slower, sexual maturity is reached later. This might be the reason why these populations show fewer individuals (or none at all) reproducing on the first year (Jażdżewski, 1969; Wägele, 1979; Bamber, 1985). In the case of a population located on southwest Sweden (Ólafsson and Persson, 1986), this scenario was so extreme that the authors rejected the hypothesis of protogynous hermaphroditism, based on the fact that organisms only reached sexual maturity at their second (and last) year of life.

The low sex ratio values observed in the Mondego Estuary may have some ecological significance, suggesting male's capability to inseminate several females (Bamber, 1985). Nonetheless, the observed decline of sex ratio from $1 / 3$ in 1993 to approximately less than $1 / 5$ in 1995 may endanger population reproduction capacity and species continuity.

The presence of green macroalgae apparently favoured the abundance of ovigerous females, probably due to better shelter and more food resources (Everett, 1994; Raffaelli et al., 1998; Norkko et al., 2000; Pardal et al., 2000; Cardoso et al., 2002). Yet, it affected negatively the recruitment of juveniles. Macroalgae might promote juvenile dispersion to adjacent areas and/or induce differential mortality, as a result of the effects induced by their presence (e.g. decrease of dissolved oxygen, entrapment on the algae matrix, etc.). Also, the possibility of embryo loss, when females are subjected to environmental stress, cannot be excluded. The most evident negative impact of green macroalgae on Cyathura carinata was the decrease in recruitment success. In opposition to Martins et al. (1997), who suggested lower survival rates due to the coincident occurrence of events (post-reproduction mortality and the algal crash), cyathurans seem to be rather tolerant to hypoxia conditions (Burbanck and Burbanck, 1979; personal observation). This tolerance may explain the fact that $C$. carinata was comparatively less affected by the algal crash than other macroinvertebrates at the Mondego Estuary (Pardal et al., 2000, 2004; Cardoso et al., 2002, 2004; Dolbeth et al., 2003).

\subsection{Production}

Growth production and mean population biomass of Cyathura carinata increased during the development of green macroalgae, which was evident from the values estimated for spring periods. Still, if the presence of macroalgae appeared to represent an immediate benefit for the population, in their absence, production values seemed to be more constant and well balanced throughout the year. Overall, growth production at the eutrophic area was comparatively much higher than values estimated for other populations (Table 1).

\section{Conclusions}

In general, the comparison of several Cyathura carinata populations (Table 1) points to the conclusion that there is a latitudinal gradient reflected in the biological features of the species. This gradient, from north to south of Europe, can be described as follows: (a) clinal variation towards continuous growth during life; (b) earlier sexual maturity in southern latitudes, anticipation of the recruitment period and evidence of protogynous hermaphroditism; (c) increase in the proportion of individuals able to reproduce after completing 1-year, with consequent post-reproduction mortality reducing the number of isopods capable of achieving the estimated life span; (d) decrease in the sex ratio (males/ females), and (e) shorter life span (controversial characteristic according to Ólafsson and Persson's (1986) results that all populations have a life span no longer than 2 years). Still, all presented univoltine life cycles, with a single generation each year. The population of the Mondego Estuary follows all these southern characteristics.

Facing the threat of eutrophication, macroalgal blooms do have negative effects over Cyathura carinata, especially on its reproductive success and secondary production. Still, $C$. carinata is a resilient species. Therefore, a single isolated bloom does not represent a severe threat. However, in the absence of a reproducing population nearby eutrophic areas, repeated events will endanger the species and ultimately, will lead to its eradication from affected estuaries.

\section{Acknowledgments}

This paper was supported by the FCT (Portuguese Foundation for Science and Technology) through a grant to S.M. Ferreira (SFRH/BM/437/2000). The authors are grateful to all colleagues from IMARCoimbra. Special thanks are addressed to Bernie Patten from the University of Georgia, for the first English revision of our manuscript.

\section{References}

Amanieu, M., 1969. Variations saisonnières de la taille et cycle reproducteur à Arcachon de Cyathura carinata (Krøyer). Journal of Experimental Marine Biology and Ecology 4, 79-89.

Argano, R., 1979. Guide per il Riconoscimento delle specie animali delle acque interne italiene - 5. - Isopodi (Crustacea Isopoda). Collana del Projetto Finalizzato "Promozione della Qualità dell'Ambiente". Consiglio Nazionale delle Ricerche AQ/1/43, Verona, p. 63.

Bamber, R.N., 1985. The autoecology of Cyathura carinata (Crustacea: Isopoda) in a cooling water discharge lagoon. Journal of the Marine Biological Association of the United Kingdom 65, 181-194.

Beukema, J.J., Flach, G.C., Dekker, R., Starink, M., 1999. A longterm study of the recovery of the macrozoobenthos on large 
defaunated plots on a tidal flat in the Wadden Sea. Journal of Sea Research 42, 235-254.

Burbanck, W.D., Burbanck, M.P., 1979. Cyathura (Arthropoda: Crustacea: Isopoda: Anthuridae). In: Hart Jr., C.W., Fuller, S.L.H. (Eds.), Pollution Ecology of Estuarine Invertebrates. Academic Press, New York, pp. 293-323.

Cardoso, P.G., Lillebø, A.I., Pardal, M.A., Ferreira, S.M., Marques, J.C., 2002. The effect of different primary producers on Hydrobia ulvae population dynamics: a case study in temperate intertidal estuary. Journal of Experimental Marine Biology and Ecology 277, 173-195.

Cardoso, P.G., Pardal, M.A., Lillebø, A.I., Ferreira, S.M., Raffaelli, D., Marques, J.C., 2004. Dynamic changes in seagrass assemblages under eutrophication and implications for recovery. Journal of Experimental Marine Biology and Ecology 302, 233-248.

Cassie, R.M., 1954. Some use of probability paper in the analysis of size-frequency distributions. Australian Journal of Marine and Freshwater Research 5, 513-522.

Cléret, J.-J., 1959. Polytypisme antennulaire et rapport numérique des sexes chez Cyathura carinata (Kröyer) (Isopode, Anthuridae). Compte rendus Hebdomadaire des Séances de l'Académie des Sciences 248, 2508-2510.

Cléret, J.-J., 1960. Étude de Cyathura carinata (Kröyer) (Isopode, Anthuridae). 1. Redescription de l'éspèce et discussion systématique. Cahiers de Biologie Marine 1, 433-452.

Dolbeth, M., Pardal, M.A., Lillebø, A.I., Azeiteiro, U., Marques, J.C., 2003. Short- and long-term effects of eutrophication on the secondary production of an intertidal macrobenthic community. Marine Biology 143, 1229-1238.

Everett, R.A., 1994. Macroalgae in marine soft sediment communities: effects on benthic faunal assemblages. Journal of Experimental Marine Biology and Ecology 175, 253-274.

Gaschütz, G., Pauly, D., David, N., 1980. A versatile basic program for fitting weight and seasonally oscillating length growth data. ICES CM G24, pp. 1-23.

Jażdżewski, K., 1969. Biology of two hermaphroditic Crustacea, Cyathura carinata (Krøyer) (Isopoda) and Heterotanais oerstedi (Krøyer) (Tanaidacea) in waters of the Polish Baltic Sea. Zoologica Poloniae 19, 5-25.

Jensen, K.T., Ferreira, S.M., Pardal, M.A. Trematodes in a Cyathura carinata population from a temperate intertidal estuary: infection patterns and impact on host. Journal of the Marine Biological Association of the United Kingdom 84, in press.

Köhn, V.J., Sammour, M., 1990. Untersuchungen zur biologie von Cyathura carinata (Krøyer, 1948) (Isopoda, Anthuridea) in einem flachwassergebiet de Wismarer Bucht (Westliche Ostsee). Zoologischer Anzeiger 224 (5/6), 297-306.

Legrand, J.J., Juchault, P., 1963. Mise en évidence d'un hermaphrodisme protogynique fonctionnel chez l'Isopode Anthuridé Cyathura carinata (Krøyer) et étude du mécanisme de l'inversion sexuelle. Compte rendus Hebdomadaire des Séances de l'Académie des Sciences 256, 2931-2933.

Marques, J.C., Martins, I., Teles-Ferreira, C., Cruz, S., 1994. Population dynamics, life history, and production of Cyathura carinata (Krøyer) (Isopoda: Anthuridae) in the Mondego Estuary, Portugal. Journal of Crustacean Biology 14, 258-272.

Marques, J.C., Pardal, M.A., Nielsen, S.N., Jørgensen, S.E., 1997. Analysis of the properties of exergy and biodiversity along an estuarine gradient of eutrophication. Ecological Modelling 102, 155-167.
Marques, J.C., Nielsen, S.N., Pardal, M.A., Jørgensen, S.E., 2003. Impact of eutrophication and river management within a framework of ecosystem theories. Ecological Modelling 166, 147-168.

Martins, I., Marques, J.C., Jørgensen, S.E., Nielsen, S.N., 1997. Modelling the effects of green macroalgal blooms on the population dynamics of Cyathura carinata (Crustacea: Isopoda) in an eutrophic estuary. Ecological Modelling 102, 33-53.

Martins, I., Pardal, M.A., Lillebø, A.I., Flindt, M.R., Marques, J.C., 2001. Hydrodynamics as a major factor controlling the occurrence of green macroalgal blooms in a eutrophic estuary. A case study on the influence of precipitation and river management. Estuarine, Coastal and Shelf Science 52, 165-177.

McMahon, K., Walker, D.I., 1998. Fate of seasonal, terrestrial nutrient inputs to a shallow seagrass dominated embayment. Estuarine, Coastal and Shelf Science 46, 15-25.

Muus, B.J., 1967. The fauna of Danish estuaries and lagoons. Distribution and ecology of dominating species in the shallow reaches of the mesohaline zone. Meddelelser Fra Danmarks Fiskeri Og Havundersøgelser 5, 1-316.

Norkko, A., Bonsdorff, E., 1996a. Rapid zoobenthic community responses to accumulations of drifting algae. Marine Ecology Progress Series 131, 143-157.

Norkko, A., Bonsdorff, E., 1996b. Population responses of coastal zoobenthos to stress induced by drifting algal mats. Marine Ecology Progress Series 140, 141-151.

Norkko, A., Bonsdorff, E., Norkko, A., 2000. Drifting algal mats as an alternative habitat for benthic invertebrates: species specific responses to a transient resource. Journal of Experimental Marine Biology and Ecology 248, 79-104.

Ólafsson, E.B., Persson, L.-E., 1986. Distribution, life cycle and demography in a brackish water population of the isopod Cyathura carinata (Kröyer) (Crustacea). Estuarine, Coastal and Shelf Science 23, 673-687.

Pardal, M.A., Marques, J.C., Metelo, I., Lillebø, A.I., Flindt, M.R., 2000. Impact of eutrophication on the life cycle, population dynamics and production of Amphithoe valida (Amphipoda) along an estuarine spatial gradient (Mondego Estuary, Portugal). Marine Ecology Progress Series 196, 207-219.

Pardal, M.A., Cardoso, P.G., Sousa, J.P., Marques, J.C., Raffaelli, D., 2004. Assessing environmental quality: a novel approach. Marine Ecology Progress Series 267, 1-8.

Raffaelli, D.G., Raven, J.A., Poole, L.J., 1998. Ecological impact of green macroalgal blooms. Oceanography and Marine Biology 36, 97-125.

Sfriso, A., Birkmeyer, T., Ghetti, P.F., 2001. Benthic macrofauna changes in areas of Venice lagoon populated by seagrasses or seaweeds. Marine Environmental Research 52, 323-349.

Sola, J.C., Arzubialde, M., 1993. Dinámica de poblaciones y biología de Cyathura carinata en el estuario del Bidasoa. Publicaciones Especiales del Instituto Español de Oceanografía 11, $57-64$.

Wägele, J.-W., 1979. Der fortpflanzungszyklus von Cyathura carinata (Isopoda, Anthuridae) in Nord-Ostsee-Kanal. Helgoländer wissenschaftlich Meeresuntersuchungen 32, 295-304.

Wooldridge, T.H., Callahan, R., 2000. The effects of a single freshwater release into the Kromme Estuary. 3: estuarine zooplankton response. Water South Africa 26, 311-317.

Zar, J.H., 1996. Biostatistical Analysis, third ed. Prentice Hall International, London, $662 \mathrm{pp}$ 